\title{
Legal Clinics and
}

Professional Skills

Development in Nigeria

\section{S.K Mokidi and C.A. Agbebaku*}

\section{Introduction}

The educational sector has a direct bearing on the social, economic, political and scientific development of a nation hence there have been increased anxieties, in recent times, about the deteriorating state of Nigeria's educational system. The growing concerns stem from the quality of our university graduates, which has become less than satisfactory and the law graduates are no exception. Thus there is a growing demand for reforms not only in the training of lawyers but of the entire educational system in Nigeria.

The declining professional skills of lawyers has taken an alarming trend over the last decade with the result that, clients most often do not get value for money paid for legal services and society does not also feel the much needed impact of lawyers. The present situation is attributed to a number of factors ranging from inadequate curriculum, inadequate manpower and training facilities both in the universities and the Nigerian Law School, to unfavourable government educational policies.

The challenges confronting the 21st century Nigerian lawyer are growing every day. Some fifty years ago not many people in Nigeria knew about the computer or knew about Deoxyribonucleic Acid (DNA) test or how to apply it in evidence. Today the computer is a necessary household facility in Nigeria; today we are faced with the problem of how to apply electronic generated evidence. The modern lawyer must be relevant to his ${ }^{1}$ society and so should be concerned not only about representing his client in court and making money for himself but with how the law can be used to resolve disputes peacefully, redress injustice and help in the emancipation and social wellbeing of the less privileged in his society.

There appears to be a consensus of opinion among Nigerians that the present method of training lawyers has become inadequate and that if the modern Nigerian lawyer must confront these challenges, there is a need to overhaul the entire legal system particularly the method of training. Bayo Ojo, writing on the need to reform legal education said "I would like to reiterate that there is urgent need to reform the whole system of producing lawyers in the country...For the past four

* Lecturers, Faculty of Law Ambrose Alli University Ekpoma, Nigeria. This paper was first delivered at the International Journal of Clinical Legal Education Conference in Newcastle upon Tyne, July 2010.

1 All references in this piece indicating the masculine gender are intended to refer equally to the feminine unless the context clearly indicates otherwise 
decades or so, there had been no review of legal education programme inspite of the fact that the country has undergone profound changes"2

Some opinion writers have advocated increase in the length of training, and continuous legal education as antidotes to the problem of declining legal skills while others suggest a review of the entire legal education curriculum to reflect the changing face of the legal profession. One of the advocates of a review of the legal curriculum and the teaching methodology, in our Universities is Ernest Ojukwu³.

This paper, synthesizes the various views that have been articulated on how to reform legal education in Nigeria with the objective of developing the professional skills of lawyers at a formative stage. It traces the history of the legal profession in the country and the society's expectation of lawyers. Drawing from our experience on the students' 'law offices' in our university, this paper posits that introduction of the clinical method of training at the academic stage of our legal education can help to arrest the current unacceptable trend of declining skills.

\section{BRIEF HISTORY OF LEGAL PROFESSION IN NIGERIA}

Due to Nigeria's historical nexus with Britain, the legal profession in Nigeria is historically connected with the English legal system and legal profession. Before, the advent of colonial rule, the various ethnic nationalities that existed in the territory now known as Nigeria had their traditional methods of dispute resolution and maintenance of law and order. With the annexation of Lagos and the introduction of colonial rule all that changed. In 1861 Lagos become a British colony. Until the amalgamation of 1914, Nigeria consisted of the Northern and Southern protectorates and the colony of Lagos.

When Nigeria came under British tutelage with the attendant social-economic changes, the British Government needed to establish and assert its authority in order to protect its commercial interest. The result was the introduction of the English common law with its methods of dispute resolution and adjudication, which were alien to the indigenous people. The laws applied were meant to secure economic and commercial advantages for the colonial power. This no doubt accounts for why the first set of indigenous lawyers in Nigeria came from the early coastal settlements, which were mainly trade centres ${ }^{4}$ and the predominance of foreigners on the Bench, in the preindependence era ${ }^{5}$.

Before the attainment of Nigeria's independence in 1960, there existed no institutions for the training of lawyers in the country and Nigerians had to travel abroad, particularly England for legal training. In England, they were trained either as barrister or solicitors. A three-month postcall practical course and one year pupilage in a law chambers was required for a Barrister who

2 The Punch, October 2, 2006 p.42. Bayo Ojo was a former president of the Nigerian Bar Association and former Attorney General of the Federal Republic of Nigeria. Similarly, in Vanguard, 12 May, 2006 p.34 while writing on the need to shift focus from litigation to lawyer's development he opined that the legal education curriculum either in the University or Law school is no longer broad and good enough.

3 Ernest Ojukwu is the Deputy Director of the Nigerian Law School, Enugu Campus and the President Network of University Legal Aid Institutions (NULAI Nigeria).

4 Balogun H. Aderinsola, "Upsurge of Lawyers in the Last Two Decades: Challenges, Problems and Solutions" Being a paper delivered at the 1999 Nigerian Bar Association Annual Conference held at Kwara Hotel Ilorin, Nigeria.

5 Kehinde Sofola SAN, Keynote Address at the Nigerian Bar Association 1999 Annual Conference, Ilorin, Nigeria 
intended to practice in England, but it was not a requirement for lawyers who did not intend to practice in England. On coming home, the English trained lawyer enrolled at the Supreme Court and practiced as Barrister and Solicitor. It is on record that the first indigenous lawyer to enroll at the Supreme Court was Christopher Alexander Sapara Williams.

The English trained lawyer who then came back home to practice law had some deficiencies:

1. While in England he studied as either a barrister or solicitor but on coming home he was faced with a fused profession.

2. In England he studied the English legal system and constitutional Law but on coming home he found that Nigeria was a federation. He had no knowledge of Nigerian customary law, which is an integral part of our legal system.

3. Until 1967 there were no mandatory courses of lectures for aspirants and a university degree was not also required and as earlier stated they were not required to do the one year mandatory attachment to chambers for those who wished to practice in England.

It was as a result of these deficiencies that the E.I.G. Unsworth Committee was set up in April 1959 to deliberate on future of the Nigerian Legal profession and made recommendations. The committee, among other things, recommended the establishment of the Nigerian Law School at Lagos for practical training and examinations. Following the enactment of the Legal Education Act of 1962 the Nigerian Law School was established in 1962 in Lagos and it took off in January 1963 with an initial eight students.

As earlier observed, in the colonial era there were no formal institutions for the training of lawyers. In 1961, the first law faculty was established at the University of Nsukka and this was followed by the establishment of law faculties at the University of Ife (now Obafemi Awolowo University) in 1961, Ahmadu Bello University Zaria in 1962 and the University of Lagos in 1965. With the establishment of these pioneer law faculties and the Nigerian Law School the stage was set for the training of lawyers in Nigeria.

\section{DO WE NEED A REFORM OF LEGAL EDUCATION?}

The Nigerian Universities Commission (NUC) and the Council for Legal Education ('Council') control legal education in Nigeria and it is in two stages. The first stage is the academic training at university while the second is the vocational training at the Nigerian Law School. The academic stage involves the acquisition of university education leading to the award of Bachelor of Laws (LL.B) degree. ${ }^{6}$

The LL.B is a five-year program for those students who entered university through the University Matriculation Examination (UME) and four years for those who entered through the direct entry. ${ }^{7}$ At the academic stage the focus is on stuffing the student with legal principles and basic tools of

6 To ensure minimum standards the NUC designs a uniform curriculum, which the Council approves for all faculties of law.

7 To qualify for admission by UME to study law the candidate must possess a minimum of the senior secondary school certificate or its equivalent with at least five credits at a sitting; for the direct entry he must have a minimum of GCE 'Advanced' level or its equivalent. Prior to the NUC report on minimum academic standard for legal education from 1990/1991 academic session the LL.B programme was four years for those who entered by UME and three years for direct entry. 
legal analysis. According to NUC in its minimum academic standards for law "Academic legal education should therefore act, first, as a stimulus to stir the student into the critical analysis and examination of the prevailing social, economic and political systems of his community and, secondly, as an intellectual exercise aimed at studying and assessing the operation, efficacy and relevance of various rules of law in society." The above encapsulates the basic objectives of the LL.B programme of the various law faculties in Nigeria.

In line with the objectives and in accordance with the NUC prescribed curriculum, all the law faculties in Nigeria must teach twelve core courses- Law of Contract, Criminal Law, Legal System, Constitutional Law, Torts, Commercial Law, Equity and Trust, Evidence, Land Law, Company Law, Jurisprudence, Legal Methods- and a compulsory Long Essay. There are also compulsory non-law courses like Use of English, History and Philosophy of Science, Logic and Philosophic Thoughts, Nigerian People and Culture, and Introduction to Computer application. In addition, there are optional law and non-law courses from which the law student is expected to choose to make up the required credit load. ${ }^{8}$ As submitted by Onalaja, the curriculum is sufficient and capable of delivering a sound academic legal education because this stage is concerned primarily with the search for principles and not to teach students all the knowledge that they would require to practice" 9

On successful completion of the LL.B programme, the law graduate proceeds to the second stage, which is the one-year vocational training at Nigerian Law School. The training at the Nigerian Law School is expected to equip the student with requisite practice skills to meet the needs of a fused profession and to effectively function in a globalised world. Towards this end, procedural courses are taught in the Law School. The courses are Legal Drafting and Conveyance, Civil procedure, Criminal Procedure, Company Law, Commercial Practice, Law of Evidence and General Paper which consists of professional ethics, law office management, legal skills and solicitor's accounts. At the end of the course and on passing the prescribed examination, the Council of Legal Education issues the law graduate with a qualifying certificate. He is then called to the Nigerian Bar, if he is certified and found fit and proper by the Body of Benchers.

We have seen the circumstances that led to the setting up of E.I.G. Unsworth's Committee that recommended the establishment of the law School. The Unsworth report was to serve as a blue print for tackling the challenges of the legal profession then, and for shaping the future of the Nigerian Legal profession. The question is whether that report of 1959 can still serve the needs of the legal profession for the 21 st Century? Aderinsola is of the opinion that it cannot. ${ }^{10}$ Ernest Ojukwu opines that although the "Nigerian Law School is supposed to be a school of practical studies, but with no properly formulated objective it is impossible to determine if its outcomes are meeting any set goals." 11

There is a general consensus that there is a sharp decline in basic professional skills of entrants in

8 The optional law courses include Customary Law, Intellectual Property Law, Revenue and Taxation law, Oil and Gas law, Labour law, Administrative law, Law of Banking and Insurance, International law, Legal Drafting and Conveyance and in some cases procedural laws like Civil and Criminal Procedure.

9 Onalaja M.O., "Problems of Legal Education in Nigeria" in The Guardian December 13, 2005 p.68

10 Aderinsola, supra note 3

11 Ojukwu Ernest, "Crisis of Legal Education in Nigeria: Need for Reform or attitudinal Change? in Niki Tobi ed. A living Judicial Legend: Essays in Honour of Justice Karibi Whyte (CON) ( Lagos, Florence \& Lambard, 2006) p. 249 at 252. 
the legal profession in recent years, and this is glaring in their performance in court, preparation of legal documents and offering of professional advice, ethics etc. Yet the quality of justice we get depends on the quality of lawyers we produce. We must concede, as observed by Justice M.M. Akanbi (rtd) at the 1999 NBA annual conference in Ilorin, Nigeria, that just as the training of a child starts from the cradle in the home and the schools he attends in his formative years, so does the training of a lawyer and acquisition of professional skills start from the university and the law school. ${ }^{12}$

The patent deficiencies in some of our young lawyers are directly related to their training both at academic stage and the law school. At the university in the majority of cases, no attention is ever paid to the teaching of practical skills because it is generally believed that 'academic legal education is concerned primarily with the search for principles and practical training should be left for Law School. This is not just the only problem. The major problem is that the much of the quality of teaching is diminishing and some of it is grossly inadequate. It is either that 'handouts' prepared in form of lecture notes are sold to students or the teaching is merely reduced to dictating of notes copied obviously from books without any attempt to update them or both. The result therefore, is that there is little or no time for meaningful interaction between the students and the teachers. ${ }^{13}$ Whereas in times past, tutorial classes were reserved for interactive engagement between the teacher and the students this is hardly the case today.

Another problem is that teaching at the law faculties of our universities is still restricted to the traditional subjects, which limits the student's scope. In today's globalised world the lawyer is more exposed to diverse societal challenges than our great forebears. Today much attention is being given to human right issues; attention is shifting to alternative method of dispute resolution, information technology, e-commerce, e-law, and Internet law etc. These are emerging trends and specialist areas, which ought to be introduced in our law faculties rather than slavish adherence to the traditional subjects. Clement Akpamgbo a former Attorney General of Nigeria seems to have echoed this view when he said: "Tomorrow's lawyer, if he to be relevant cannot just be a lawyer familiar with rules of procedure of our courts with smattering knowledge of substantive law... he should be familiar with the various regional economic treaties and conventions and their implication for trade and business in the African region". ${ }^{14}$

The law school that is assigned the role of practical training of the lawyer has not fared better. What has emerged over the years is that the teaching method is not remarkably different from what is obtainable in the universities. There are hardly moot/mock trials and only a few students participate, if they are held at all. The tutorial classes are conducted at the approach of the examinations and tailored towards the students passing the prescribed examinations.

In the course of training at the law school students are sent on law offices and courts attachment to familiarize themselves with general office work, legal practice, legal research and appreciate the ethics of the profession thus exposing them to practical skills but each of these attachments do not normally exceed six weeks. Experience has shown that students see the period as an opportunity to read the voluminous notes they received in school and, in the absence of close monitoring by the Law school, the students do not take the attachments seriously. The result is that most students

12 A paper presented at the 1999 NBA Conference held at Ilorin, Nigeria

13 Ojukwu Ernest, supra note 10.

14 Address at the Law Teacher's Conference, on 27 $7^{\text {th }}$ April, 1992, at Ogun State University, Ago-Iwoye. 
gain nothing from the exercise.

\section{THE LAWYER AND SOCIETAL CHALLENGES}

Law is an instrument of social engineering. Indeed, the legal profession plays a dominant role in any society because all human activities revolve within a legal framework. Lawyers are known to have and still make tremendous contributions to the social, political and economical development of their societies. As observed by Bayo Ojo, lawyers in the United States, for instance, were in the forefront of the struggle for constitutionalism and feature prominently in the chronicles of the American Revolution ${ }^{15}$. Emphasizing the importance of lawyers in the society Newton D, in an address at the Columbia University in 1993, stated: "One of my deepest conviction is that so far as the institutional progress of a people is concerned its salvation lies in the hands of the profession of the Bar"16

Indeed, the public repose much confidence in the lawyer as the 'learned man' to help advise government, commerce, industry and private citizen; he is seen as a defender of human rights and promoter of the rule of law. Olisa Agbakoba, former president of the Nigerian Bar Association captured the challenges facing the modern lawyer in Nigeria when he said:

"Our great forbears in this profession did not have to contend with the challenging realities of the internet and globalization, they lived and practiced our profession before deregulation economic and political reforms, and fast spaced transnational environment that we must live with in today's Nigeria. Our practice environment changes around us by the minute. The challenges that confront us as citizens and professionals are evolving rapidly. If we are to approach anywhere close to the respect that our great professional forbears commanded in their time, then we have to go the extra mile to renew our profession and build a 21st century Bar for the Nigeria of tomorrow." 17

If the institutional progress of a people depends so much on the lawyer then he must be a part of the society he lives and understand it if he is to be able to participate in its development and the economic and social well being of its members. The modern lawyer must be sufficiently equipped in knowledge and skill to assume his role and it is submitted that the training of the Nigerian lawyer must go beyond the traditional functions and incorporate those areas that will bring social changes. Otherwise, as suggested by Karibi-White such a training is bound to be myopic and likely to deal with societal problems in a truncated manner ${ }^{18}$.

What we have tried to do so far in this rough historical excursion is to show why the existing legal curriculum and teaching method can no longer meet the needs of the 21 st century legal profession. To continue to maintain it will merely lead to producing what Sam Amadi referred to as lawyers "simply trained to function as bricklayers whose mind [is] the 'job' of adding one block after another, without a clear vision of what edifice is being constructed" 19 .

15 Bayo Ojo supra note 1

16 Cited in Onalaja M.O., supra note 8

17 Agbakoba O., "Re-imagining the $21^{\text {st }}$ Century Nigerian Lawyer" in Vanguard, 6 October, 2006 p.44

18 Karibi-Whyte JSC cited in Nuhu Mohammed Jamo, "Upsurge of Lawyers in the Last Two Decades: Challenges, Problems and Solutions being paper presented at 1999 NBA Annual Conference held in Ilorin

19 Amadi S, legal Education, Public Interest Lawyering and Social Justice in Nigerian Bar Journal vol 2 No.2 2004 


\section{LEGAL CLINICS AND PROFESSIONAL SKILLS}

A good cause also needs a good lawyer. A good advocate can deploy his good skills to turn an otherwise bad case to good against a weak advocate. The impact of globalisation is changing the face of legal practice and Nigeria as an emerging democracy must begin to think of what role it wants lawyers to play in its political, social, cultural and economic development. Today, issues like high-jacking, kidnapping, piracy, delay in administration of Justice, human rights abuses e.t.c, stare us in the face. An understanding of these problems can help us reshape and redefine the structure and contents of our legal education.

Faced with these numerous challenges, the lawyer should have the requisite skills to function effectively. It is generally agreed that the legal curriculum is such that the university training is theoretical and not practice oriented, yet good knowledge of principles is not sufficient to prepare the students for today's legal practice when eventually called to Bar. This underscores the need for introduction of a practice oriented method of training at the various faculties of law because a lawyer must be well equipped to apply knowledge of principles to solve legal problem.

Legal skills refer to the ability to apply knowledge of law to solve legal problems. The basic skills that a lawyer requires are in the area of advocacy, legal drafting, negotiations, legal research, management and verbal communication. To understand the role law clinics will play in these, we must consider the goals of clinical legal education. Clinical education requires the student to learn by doing; it therefore requires his active participation. The objective is to train lawyers who will be highly skilled, effective and responsible in whatever capacity they find themselves. Through the student's active participation in the process of learning, he is exposed not only to legal skills but also to the essential values of the legal profession: provision of competent representation, promotion of justice, fairness and morality; continuing improvement of the profession, and professional self development. ${ }^{20}$

At this stage a brief consideration of the activities of students' 'law offices' in the faculty of law, Ambrose Alli University Nigeria will, by way of analogy, help us understand how law clinics would help in skills development. ${ }^{21}$ In the faculty of law students are encouraged to join any of the student operated 'law offices' and 'counsel' in these offices 'practice' before 'courts' in the University ${ }^{22}$. The students take on live cases affecting students and in the process are involved in extensive research, drafting, and legal representation in court. Where the matter is purely civil and the need for litigation arises, pleadings may be filed and the students may consider it necessary to consult with their staff adviser or legal practitioners. ${ }^{23}$ Decisions of the 'Courts,' in cases affecting law students only, are transmitted to faculty of law management for enforcement while those involving other students are sent to University management through the Dean of Students' Affairs

20 Margaret Martin Barry et al, Clinical Education for this Millennium: the Third Wave, 7 Clinical L. Rev 1, 13 (fall 2000)

21 Student 'Law Offices' which operate only in the faculty of law are neither law clinics nor products of law clinic in the faculty. They are formed and managed by law students but are required to be registered with the Law Students Association (LAWSA). They are named after notable legal practitioners and jurists.

22 The courts are the LAWSA Jural Court, the Students Union Government High Court and the Supreme Court, which are manned by students except that the dean of law is the chief justice of the Supreme Court.

23 They also provide legal representation in matters like violation of dress code which are considered as quasi criminal and prosecuted by the LAWSA Attorney General 
for enforcement ${ }^{24}$.

Unfortunately, because the management of these 'law offices' is left in the hands of students much of the emphasis is on advocacy such that little attention is paid to developing other legal skills. Again, because membership is voluntary and no academic credit is attached the level of participation by students is low. However, experience has shown that students who are members of these 'law offices' form the nucleus of those that do represent the faculty in moot trial competitions. The success the faculty has recorded in national and international competitions can be attributed to the skills gained from the students' participation in these 'law offices'. The experience gained at this formative stage has also helped a good number of them in legal practice; some have turned out to be notable human rights crusaders ${ }^{25}$.

We have also found that since the establishment of the faculty law clinic a greater number of our student clinicians, who are enthusiastic about the programme, are members of these students' law offices notwithstanding the fact that the law clinic is open to all students in year three and four who offer legal practice as a course. ${ }^{26}$ The point being made here is that drawing from the gains of these campus law offices we can safely say that there is a need to introduce some form of practical training at the university stage in the training of our lawyers. Indeed this is the objective of setting up law clinics in the Universities- expose students in their early life to practical training and experience about the justice delivery system.

The training of our lawyers should focus on achieving public good. Our personal experience reveals that a good number of those who aspire to study law in Nigeria, do so because of the notion that a lawyer is influential and 'a big man' in the society and not because of any commitment to development of his society through promotion of rule of law, protection of human rights or service to the less privileged in the society. The introduction of clinical legal education in law faculties will change this attitude and lay the foundation for law students to carry with them throughout their professional careers as attorneys a great sense of professional commitment to the ethics and values of public service. ${ }^{27}$ The recent experience from the prison visits undertaken by the clinicians in the faculty reveals that with proper training we can have lawyers whose main focus will not only be litigation but service delivery to their community ${ }^{28}$.

Lawyer's skills are acquired through practical experience and that experience can as well start at the Universities rather than wait for the one-year vocational training at the Nigerian Law School. Law Students should have that opportunity of familiarizing themselves with general office work,

24 The "Cases" are usually disputes emanating from Union and associations' elections, violation of dress code, issues bordering the running of the Students' Union Government and other matters, whether contractual or tortious between students. They do not accept briefs involving students and non-students.

25 It is on record that the faculty of law Ambrose Alli University participated at the All African Human Rights Moot Court competition 1999, won Justice M.M. Akanbi's Interfaculty Debate 2002, James Iboris' cup for Advocacy 2002, Wole Olufon CLASFON best Advocate prize five consecutive times, National championships of the Phillips C. Jessup International Law Moot court competition 2003, 2004 and 2005, and represented Nigeria in World Championship in Washington, D.C April 2005 and 2006

26 Legal Practice 1 and legal practice 2 are compulsory elective for law students in year 3 and 4 respectively.

27 See Yemi Akinseye - George, "Legal Aid and University Law Clinics in Nigeria" in Nigerian Bar Journal vol 2 No. 2 (2004) 173 at 175.

28 The enthusiasm displayed by the students during the visits and follows up amply demonstrated their commitment to access to justice for the less privileged. 
legal practice, legal research, and inculcate the ethics of the legal profession. ${ }^{29}$ Herein lies the justification for the introduction of clinical education in our faculties. Law clinics will fill the lacuna in the legal curriculum for the following reasons:

- Law clinics provide legal services to the poor who would not ordinarily have been able to access justice. Through contact with clients, the participants are able to internalise the value of public services. ${ }^{30}$

- By meeting with and relating to people of differing backgrounds and perspectives, participants are able to understand their viewpoints and beliefs particularly in a multi-ethnic and cultural society like Nigeria. This will help the lawyer in actual practice.

- Participation in law clinics enables the law student to inculcate the spirit of legal research thereby constantly updating his knowledge of law.

- Clinicians, through full involvement in the management of the clinics are able to acquire basic skills in drafting and law office management.

- Serving as paralegals will integrate the students into the real workings of the legal profession. ${ }^{31}$

- Interactive teaching methodology enables student to have a better understanding of the subject. Again by observing and experiencing it the student is placed in a better position to remember what he was taught.

\section{Envisaged Problems}

There is no gainsaying that clinical education offers the students a unique opportunity to learn and develop practical skills. However, the introduction of clinical education in the faculties of law in Nigerian Universities will meet with certain challenges. A law clinic may be the type that deals with 'live - client' or moot/ simulation clinics; it may even be a specialized one. Although each of these has its distinct features, they share certain characteristics. The characteristics include the use of the interactive method of teaching and supervision by a clinical instructor who is an experienced practitioner.

First, a 'live-client' clinic is likely to face resistance from qualified legal practitioners who will see the clinicians as encroaching on their territory. The functions of the live-client clinic include interviewing and counseling of clients, mediation and where necessary preparation of court processes under the supervision of a qualified legal practitioner. In some jurisdictions it may involve actual legal representation in courts. In Nigeria, a law student cannot represent the client in court and cannot frank any legal document for filing in court. The reason is that only persons whose names are on the legal practitioners' role can practice as a barristers and solicitors in Nigeria $^{32}$.

29 See National Needs Assessment for the Justice Sector, NBA programme Unit (NBA 2007)

30 Legal Clinics: Serving people, improving justice, Manual of Open Society Justice Initiative p. 4

31 See National Needs Assessment for the Justice Sector, NBA programme Unit (NBA 2007) 22

32 See section 1 of the Legal Practitioners Act Chapter L11 LFN 2004. There is even the raging controversy on the issue of courtroom attendance by law teachers in view of sections 172 and 209 of the 1999 constitution of the Federal Republic of Nigeria. See particularly Giwa A.O., "Law lecturers and Courtroom Attendance" in Nigeria Bar Journal vol. 1 n0. 4 (2003) 505 and Taiwo, E.A. "Public Officers and Private Practice: The Legal Issues Arising Under the 1999 Constitution of Nigeria” in Nigerian Bar Journal Vol.3 No.2 (2005) 26. 
Another challenge is how to overcome the traditional methods of teaching that our law teachers are used to. This will involve retraining of our teachers or employing non-academic professionals with the attendant financial implications. According to Sam Amadi 33 "if we intend to run effective clinical programs in Nigeria... we should be willing to retain the services of non-academic professionals who have special and consummate skills to expose students to the 'practical' of public interest lawyering in their legal education". ${ }^{34}$ It is doubtful whether the universities are prepared to shoulder the additional financial burden of employing non-academic professionals.

Implementation of clinical legal education requires some basic infrastructures. One of the reasons for the falling standard of University education in Nigeria is lack of adequate infrastructures. For a sustainable clinical education there must be provision of audio-visual aids, adequate classrooms and furniture, information technology and adequate teaching aids including textbooks. One major problem Nigerian public universities are facing is inadequate funding and the internally generated revenue will be grossly inadequate to meet these essential requirements.

The present legal curriculum is inadequate and does not accommodate most of the practice-based subjects. For an effective clinical programme, there will be the need for curriculum development which shall include procedural courses, moot trials, research methodology and also accommodate emerging trends and specialist areas like Alternative Dispute Resolution, Mediation and Conciliation, information technology etc.

\section{CONCLUSION}

We proceeded on the premise that the declining skills of lawyers in Nigeria is attributed mainly to the training method. We tried to argue that the practice of law is becoming globalised and new issues are emerging that pose a challenge to the 21 st Century Lawyer. The 21 st century lawyer must not be estranged from his community and must be prepared to undertake public service and thereby foster professionalism. We submitted that the skills of the modern lawyer can be developed at the formative stage and clinical legal education will enable the lawyer to acquire the requisite skills early in life to face the challenges of the future. Though we conceded that the introduction of clinical legal education in Nigerian law faculties will meet with some challenges, it is submitted that they are not insurmountable.

33 Amadi Sam Supra at 156

34 In view of the restrictions on private practice by lawyers in public service, it is even doubtful whether the academic lawyer who supervises the students can impact the much-needed skills since he is not involved in everyday practice. 
